Unequal Englishes 
Also by Ruanni Tupas

LANGUAGE EDUCATION AND NATION-BUILDING

Assimilation and Shift in Southeast Asia (co-edited)

(RE)MAKING SOCIETY

The Politics of Language, Discourse and Identity in the Philippines (sole-edited) 


\section{Unequal Englishes}

\section{The Politics of Englishes Today}

Edited by

Ruanni Tupas

National Institute of Education, Singapore 
Selection and editorial content (c) Ruanni Tupas 2015

Individual chapters (C) Respective authors 2015

Foreword (c) Arjuna Parakrama 2015

Softcover reprint of the hardcover 1st edition 2015 978-1-137-46121-6

All rights reserved. No reproduction, copy or transmission of this publication may be made without written permission.

No portion of this publication may be reproduced, copied or transmitted save with written permission or in accordance with the provisions of the Copyright, Designs and Patents Act 1988, or under the terms of any licence permitting limited copying issued by the Copyright Licensing Agency, Saffron House, 6-10 Kirby Street, London EC1N 8TS.

Any person who does any unauthorized act in relation to this publication may be liable to criminal prosecution and civil claims for damages.

The authors have asserted their rights to be identified as the authors of this work in accordance with the Copyright, Designs and Patents Act 1988.

First published 2015 by

PALGRAVE MACMILLAN

Palgrave Macmillan in the UK is an imprint of Macmillan Publishers Limited, registered in England, company number 785998, of Houndmills, Basingstoke Hampshire RG21 6XS.

Palgrave Macmillan in the US is a division of St Martin's Press LLC, 175 Fifth Avenue, New York, NY 10010.

Palgrave Macmillan is the global academic imprint of the above companies and has companies and representatives throughout the world.

Palgrave ${ }^{\circledR}$ and Macmillan ${ }^{\circledR}$ are registered trademarks in the United States, the United Kingdom, Europe and other countries.

ISBN 978-1-349-49885-7

DOI $10.1057 / 9781137461223$

ISBN 978-1-137-46122-3 (eBook)

This book is printed on paper suitable for recycling and made from fully managed and sustained forest sources. Logging, pulping and manufacturing processes are expected to conform to the environmental regulations of the country of origin.

A catalogue record for this book is available from the British Library.

A catalog record for this book is available from the Library of Congress.

Typeset by MPS Limited, Chennai, India. 
FOR MILD, RUSH, RAM, AND RAIN—my inspiration, my real world 
This page intentionally left blank 


\section{Contents}

List of Figures and Tables ix

Foreword by Arjuna Parakrama $\quad$ X

Acknowledgments xiii

Notes on Contributors xiv

Introduction: From World Englishes to Unequal Englishes 1

Ruanni Tupas and Rani Rubdy

\section{Part I Approaches to Unequal Englishes}

1 Inequalities of Englishes, English Speakers, and Languages: A Critical Perspective on

Pluralist Approaches to English

Ryuko Kubota

2 Unequal Englishes, the Native Speaker, and Decolonization in TESOL

Rani Rubdy

3 Structures of Feeling in Unequal Englishes

Joseph Sung-Yul Park

4 Global English and Inequality: The Contested

Ground of Linguistic Power

Peter Ives

\section{Part II Englishes in Nexuses of Power and Inequality}

5 'Just an Old Joke': Chinglish, Narrative, and Linguistic Inequality in the Chinese English Classroom

Eric S. Henry

6 English in Japan: Indecisions, Inequalities, and

Practices of Relocalization

Glenn Toh

7 Performing Gayness and English in an Offshore Call Center Industry

Aileen O. Salonga 


\section{Part III Englishes in Changing Multilingual Spaces}

8 Earning Capital in Hawai'i's Linguistic Landscape Christina Higgins

9 Glocalization and the Spread of Unequal Englishes:

Vernacular Signs in the Center of Beijing

Lin Pan

10 Singlish Strikes Back in Singapore

Catherine Chua Siew Kheng

\section{Part IV Englishes in Unequal Learning Spaces}

11 Contesting the Raj's 'Divide and Rule' Policies:

Linguistic Apartheid, Unequal Englishes, and the Postcolonial Framework

Vaidehi Ramanathan

12 Unequal Englishes in Imagined Intercultural Interactions Phan Le Ha

13 Preparing Teachers for 'Unequal Englishes':

The D-TEIL Experience in Cuba

Ian Martin and Brian Morgan

Index 


\section{List of Figures and Tables}

\section{Figures}

8.1 Bus stop 200' makai 151

8.2 Sign posted in a restroom 151

8.3 Keiki menu 152

8.4 Sterile puka sheet 153

8.5 Carex for sale at Home Depot 155

8.6 No get my back, no get my vote 157

9.1 Geographical location of Dashilan 169

9.2 Refurbishment and reintroduction of Dashilan

9.3 Jui Fu Hsiang Hsi Huang Ghi: a 'time-honoured' silk shop 172

9.4 Xinli Xinfu silk shop 175

9.5 'U.K. Royal Sungre' men's clothing store 178

9.6 Gallery 180

10.1 The changing social and linguistic landscape
of Singapore

11.1 Local vernacular content in English language
textbooks used in Gujarati-medium classes

$\begin{array}{ll}11.2 & \text { Local vernacular content in English language } \\ \text { textbooks used in Gujarati-medium classes } & 209\end{array}$

11.3 Excerpts 210

11.4 Translation exercise 212

Tables

8.1 Raining on my parade 159

10.1 Speak Good English Movement themes 195

11.1 Divergent MLLS for Gujarati- and
English-medium students 


\section{Foreword}

At last a book that grasps the thuththiri ${ }^{1}$ of our unequally globalized Englishes problem without being defensive or apologizing for itself! I'm proud to be associated, even in so small a way, with this radical academic-interventionist enterprise that examines a wide range of key issues and implications surrounding the systemic and extra-systemic inequalities enforced against non-dominant Englishes. All credit to Ruanni Tupas who has succeeded in bringing together a remarkably diverse yet cohesive set of studies, which take as their starting point the unequal exchange between linguistic centers and peripheries.

More importantly, perhaps, the scholarship here not only documents such 'inequality', it also identifies and demonstrates local resistance to the various inter-connected strands of dominance and hegemony that non-elite users must face-locally, sub-nationally, nationally, regionally, internationally, globally — every day, whether in China, Cuba, Hawai'i, India, Malaysia, the Philippines, Singapore, South Korea, or elsewhere. Moreover, pre-empting the inevitable quasi-scholarly attempts at ghettoization that these are merely empirical and/or 'special cases' of no more than nuisance value, broader conceptual studies complement these filigreed accounts from the ground.

The conceptual problems created by over a century of colonialist and neo-colonialist 'scholarship' in Applied Linguistics, whose notso-hidden agendas are given great license even today in ESL 'studies', are so pervasive and entrenched that counter-hegemonic analyses such as these are forced to re-present the ubiquitous as exceptions. Hence, though we all know that every linguistic context is multilingual, and all spaces are unequal, in order to be heard we must present ourselves as speaking to non-typical and fundamentally non-normative case studies.

Elsewhere, I diffidently propose the notion of 'extra-linguistic value' attached to [White] English (and other contextually dominant languages/varieties) as a means of explaining the hegemony it enjoys, as well as to understand as (hidden) resistance the plethora of persistent 'errors' and 'deviations' that characterize non-elite use. The attempt is to theorize a more inclusive yet nuanced (anti-)paradigm than the 
binary between 'individual' and 'community' language use (and, of course, national/international/global vs. local/specific) which Ives so brilliantly unravels here.

The 'local' neither replaces nor reinvents (nor even seriously questions) the 'global', but is appropriated within it in the most troubling ways. Thus, celebrating our special difference is one way of validating (by default and non-contestation) the old hegemonies in language. Yet, we must, in the grossly unequal spaces we occupy, establish (over and over again) that the 'local' is even worthy of study, and that we're not doing this only because we happen to belong there.

For my own work, even 'local' has become too broad a category, and it is in sub-local (anti-)language use and abuse that I am beginning to recognize complex resistance as a form of subaltern agency which is viable only when misrecognized as imitation gone wrong. Subalternity that is characterized as the prevalence of 'dominance without hegemony' has become for me the space where 'dominance is (deliberately) misrepresented as hegemony' by recalcitrant users. This insight has been reinforced for me by the essays in this book that demonstrate the subtlety and suppleness with which ordinary bi/multi-lingual users of English stake and re-stake their claims in defiance of real-world consequences, and by the essays that advocate the fundamental questioning of cherished first-worldist paradigms in favor of a more inclusive understanding that has greater explanatory power.

The first part of the challenge is, therefore, to continue to demonstrate that there is radical difference alive and well in the interstices of the everyday outside of the mainstream (whether this be locational, classed, historical, ethnicized, gendered, age-based, or more likely in combinations of these demographies). It seems that only then will we be taken seriously when we argue that the same problematic obtains inside the mothership(s) of English. Ours are not special cases, but better gauges of how language works as a site of the heterogeneous struggles of class, race/ethnicity, gender, age, region/location, sexual orientation etc., because such struggles take place before our eyes and ears now, refusing to be covered over as in the past. ${ }^{2}$

This larger battle remains unwaged as yet, but it is worth reminding ourselves that the opposition to even such localized critique is that they/ we know what's ultimately at stake here.

Arjuna Parakrama Peradeniya, Sri Lanka 


\section{xii Foreword}

\section{Notes}

1. If you as reader are unfamiliar with this term and this worries you, please look it up, check it out, research it, spend time discovering what it is, feeling just a little annoyed (and I hope abashed too), just as you would when looking up an obscure Old English word or an unfamiliar White-English expression. When we are able to treat all such words as equal, irrespective of their origin, then we have begun travelling the impossible road to addressing linguistic inequality.

2. I use the phrase 'fast-forward change, but which takes place in slow-motion' to attempt to capture the paradox where hitherto long-drawn out changes in/of language are accelerated through (post)colonial language-contact, but at the same time since different stakeholders are more articulate than before, these changes are also tangibly contested at each stage. Thus, the gradual transformations that took place in England over a 500-year period can be seen to take place in post-colonial Englishes in 50 years, and hidden struggles that we can only speculate upon in the former case are fought out in public in the former colonies! 


\section{Acknowledgments}

Figure 8.1-Bus stop 200' makai. Reproduced with permission of Toshiaki Furukawa

Figure 8.3-Keiki menu. Reproduced with permission of Bill Tobin

Figure 8.4-Sterile puka sheet. Reproduced with permission of Marissa Hanada

Figure 8.6-No get my back, no get my vote. Reproduced with permission of Fellen Kelemente

We thank Gujarat State Board of Textbooks for the use of pages from English textbooks used in Gujarati-medium classes. 


\section{Notes on Contributors}

Catherine Chua Siew Kheng has a PhD from the School of Education, University of Queensland. She is currently Assistant Professor in the Policy and Leadership Studies Group, NIE/NTU, Singapore. Her research activities focus on the areas of twenty-first-century education, globalization and education, educational policy, language planning and policy. Her other areas of interests include culture and education, education and economy, leadership practices in school, and the role of media in educational reform. She is currently an editorial board member of Language, Culture and Curriculum, and a series editor of Language Planning and Policy.

Eric S. Henry is Assistant Professor in the Department of Anthropology at Saint Mary's University in Halifax, Canada. Based on ethnographic fieldwork in Shenyang, China, his research concerns the role of contemporary speech practices and foreign languages in China's developing sense of itself as a modern, cosmopolitan nation. His work has been published in journals such as City \& Society, Language in Society, and Anthropological Quarterly. His teaching is in the areas of linguistic anthropology, sociolinguistics, Asian studies and semiotics.

Christina Higgins is Associate Professor in the Department of Second Language Studies at the University of Hawai'i at Mānoa, where she teaches graduate courses in sociolinguistics, discourse analysis, intercultural communication, and English as a global language. Her research explores the local-global interface of language and identity in East Africa and Hawai'i. She is the author of English as a local language: Postcolonial identities and multilingual practices (2009), co-editor (with Bonny Norton) of Language and HIV/AIDS (2010), and editor of Identity formation in globalizing contexts: Language learning in the new millennium (2011).

Peter Ives is Professor of Political Science at the University of Winnipeg, Canada, where he primarily teaches political theory. He is the author of Gramsci's politics of language: Engaging the Bakhtin Circle and the Frankfurt School (2004), Language and Hegemony in Gramsci (2004) and co-editor (with Rocco Lacorte) of Gramsci, Language and Translation (2010), and, with Thomas Ricento and Yael Peled, of Language Policy and Political Theory (2015). His articles on 'global English' have been published in Political Studies, Educational Philosophy and Theory, and Language Policy. 
Ryuko Kubota is Professor of Language and Literacy Education at the University of British Columbia. Her research focuses on critical approaches to applied linguistics by drawing various inquiry approaches from cultural studies, multiculturalism, critical race theory, and critical pedagogy. She is a co-editor of Race, culture, and identities in second language: Exploring critically engaged practice (2009). Her publications also appear in such academic journals as Applied Linguistics, Critical Inquiry in Language Studies, International Journal of Bilingualism and Bilingual Education, Journal of Journal of Second Language Writing, Journal of Multilingual and Multicultural Development, Linguistics and Education, and TESOL Quarterly.

Ian Martin is Associate Professor in the English Department, Collège universitaire Glendon College, York University, Toronto, Ontario, Canada, where he coordinates the Certificate Program in the Discipline of Teaching English as an International Language (Cert D-TEIL) and teaches courses related to the Certificate as well as courses on language policy, especially for indigenous peoples of the Americas. Recently, his research has been on bilingual education policy in Nunavut Territory in the Canadian Arctic, as well as 'new literacies' and English pedagogy in a project linking Glendon with the State University of Mato Grosso do Sul, Campo Grande, Brazil.

Brian Morgan is Associate Professor in the English Department, Collège universitaire Glendon College, York University, in Toronto, Ontario, Canada, where he teaches in the Certificate Program in the Discipline of Teaching English as an International Language (Cert D-TEIL), as well as courses in content-based EAP, and graduate courses in Applied Linguistics. His primary research area is in critical theories and their potential implementation across English Language Teaching contexts. Recently, Brian has collaborated in several projects linking Glendon with Brazilian universities and scholars. Brian is also a co-editor of the Critical Language and Literacy Series.

Lin Pan is Associate Professor at the Beijing Language and Culture University (BLCU) and is a research fellow at University College London (UCL) Institute of Education. Her research interests are language ideologies, globalization, teacher education and multilingualism. Lin has publications in Language Policy, Journal of Sociolinguistics, Visual Communication, Applied Linguistic Review, Language Learning Journal, and English Today. She is the author of the book entitled English as a Global Language in China: Ideologies in language education. 
Phan Le Ha is Associate Professor in the Department of Educational Foundations, College of Education, University of Hawaii at Manoa, USA. She also holds adjunct appointments at universities in Vietnam and Australia. Her expertise include identity studies, language-culturepedagogy, TESOL, postcolonial studies, sociology of education, and international education. Dr. Phan has published widely in these areas. Her latest book is Desiring TESOL and international education: Market abuse and exploitation (co-authored with Raqib Chowdhury, 2014). Her forthcoming authored book offers to theorize various aspects and phenomena of transnational education in Asia and the Middle East.

Arjuna Parakrama is Professor of English at the University of Peradeniya. Before this he was Dean/Arts at Colombo University where he taught for over 15 years. He has published widely on language standardization and the politics of language, subaltern studies, Lankan English and teaching English in Sri Lanka, conflict transformation and discourse theory. He has been awarded a Guggenheim research grant, as well as senior fellowships from the Carnegie Council on Ethics and International Affairs, and the US Institute of Peace. He was a Fulbright New Century Scholar in 2007/8.

Joseph Sung-Yul Park is Associate Professor in the Department of English Language and Literature, National University of Singapore. He works in the areas of language and globalization, English as a global language, and language ideology. His recent work has focused on the role of English in transnationalism and neoliberalism, with a focus on the context of South Korea. He is the author of The Local Construction of a Global Language and co-author, with Lionel Wee, of Markets of English.

Vaidehi Ramanathan is Professor of Applied Sociolinguistics in the Linguistics Department at the University of California, Davis. Her research interests span all domains of literacy, including teacher-education, minority languages, and language policies as well as concerns about aging, health, and disability studies. Her publications include: Language, body and health (co-edited, 2011), Bodies and language: Health, ailments, disabilities (2010), The English-vernacular divide: Postcolonial language politics and practice (2005), The politics of TESOL education: Writing, knowledge, critical pedagogy (2002), and Alzheimer's discourse: Some sociolinguistic dimensions (1997).

Rani Rubdy has taught at the National Institute of Education, Nanyang Technological University and the National University of Singapore. Her research interests include World Englishes, globalization and its social, sociolinguistic and educational consequences, language planning and 
policy and linguistic landscapes. Her edited volumes are English in the world: Global rules, global roles (with Mario Saraceni, 2006), Language as commodity: Global structures and local marketplaces (with Peter K. W. Tan, 2008), The global-local interface and hybridity: Exploring language and identity (with Lubna Alsagoff, 2014) and Conflict, exclusion and dissent in the linguistic landscape (with Selim Ben Said, 2015).

Aileen O. Salonga is Associate Professor at the Department of English and Comparative Literature at the University of the Philippines (UP) in Diliman. She has a PhD in English Language from the National University of Singapore, and an MA in English from Virginia Tech. She writes in the areas of sociolinguistics, discourse analysis, gender and discourse studies, and translation studies, and has published on gendered spaces of globalization, gender and technology in the Philippines, and problems of rhetoric.

Glenn Toh has been an English teacher for nearly 30 years. He has taught EFL, EAP, ESP and TESOL teacher-training courses in Australia, Hong Kong, Japan, Laos, New Zealand, Singapore, and Thailand. He now teaches at the Center of English as a Lingua Franca (CELF) and the Graduate School of Humanities at Tamagawa University in Tokyo. He has written for journals in applied linguistics and maintains a keen and watchful eye on developments in language, ideology, and power.

Ruanni Tupas is Assistant Professor at the National Institute of Education (NIE), Singapore. Prior to his NIE appointment, he was Senior Lecturer at the Centre for English Language Communication (CELC) of the National University of Singapore (NUS) where he taught for ten years from 2002 to 2012. He was the 2009 Andrew Gonzalez Distinguished Professorial Chair in Linguistics and Language Education, awarded by the Linguistic Society of the Philippines (LSP) which recently has also elevated him to honorary membership. His edited book, (Re)making society: Language, discourse and identity in the Philippines, was a 2008 Philippine National Book Awards Finalist. 